\title{
Evolution of the exegesis: the radical trajectory of the creative writing doctorate in Australia
}

\begin{abstract}
This article examines the history of the creative writing doctorate in Australia and traces how its form became more radical over the last 25 years. The work of Edward Cowie, who established the first creative writing doctorate, is placed in context of developments which followed his pioneering degrees. Considering ERA, a case is made for the further radicalisation of the creative writing PhD to meet requirements for new research standards.
\end{abstract}

Keywords: exegesis, creative writing PhD, DCA, ERA

\section{Introduction}

To summarise 15 years of pre-ERA history which produced more than 200 Creative Writing doctorates in 28 Australian universities (see Boyd's survey 2009), it can be said that the changing shape of the doctorate was due to the evolving aims, focus and form of the exegesis. Creative products stayed much the same - manuscripts of novels, collections of stories, poems or playscripts were subject to the requirement of publishability and reflected a moderately stable (or inert) literary climate; but the exegesis metamorphosed. (I base this statement to a significant extent not just on the 16 doctorates with exegeses I supervised to completion from 2000 to 2010; but also I examined 32 creative writing doctorates for 18 Australian universities from 1998 to 2010. These were non-traditional submissions comprising exegesis and artefact.) This situation is unlikely to continue with ERA's greater emphasis on the creative product as groundbreaking research: both exegesis and artefact, it seems clear, now have to evolve.

In the 1990s initially, the expectation was that an exegesis should be a sort of critical journal, a reflective account of processes undertaken while creating the accompanying work, having a close umbilical relationship to it. This way of thinking derived significantly from the visual arts, where artists' journals provided reflective background to exhibitions submitted in early postgraduate awards. Academic tradition in the Fine Arts considered that journals left by painters as diverse as Da Vinci and Kahlo afforded 'clues into the painter's highly autobiographical work' (New 2005: 17). Speaking of Frida Kahlo, Sarah M Lowe says:

$[\mathrm{H}]$ er journal entries - the written passages as well as the drawings - convey the immediacy of firsthand sensations transcribed and recorded, a disclosure lacking in her paintings ... [and while] the typical artist's sketchbook ... is usually a place for preparatory drawings or working out solutions in a 
small format to be applied to large works ... Kahlo is inattentive to day-to-day goings-on, and uses her journal (as did Virginia Woolf) as a repository for feelings (and images) [that produce] an image of the artist unmasked. (Kahlo 1995: 26)

Recognition of the artist's journal as an 'unmasking' and 'disclosure', as an insight into processes informing the finished product, had a radiating effect from Visual Arts schools to other creative disciplines. In the rationale for the 1984 proposal for the first Australian doctorate in Creative Arts (at the University of Wollongong) Professor Edward Cowie wrote:

"Many Artists have given ample evidence of their ability to articulate in conventional academic terms the nature of the creative process in action. The Artist Paul Klee was an example of an Artist who saw the relationship between theoretical study and practical application ..." (Cowie quoted in Bell 1998: 110)

Cowie cited Klee's “"The Pedagogical Sketchbook, and massive series of notes and ideas now called The Thinking Eye"' (Cowie quoted in Bell 1998: 110), along with works about creative process by Kandinsky, Schoenberg and TS Eliot, in support of the notion that creative practitioners were capable of academic analysis of their own practice and of the contexts in which their practice was placed.

This notion was, of course, anathema. It was widely held in the 1980s that creative artists were incapable of scholastic rigour or strategic thinking. Much of DG Myers' book The Elephants Teach: Creative Writing Since 1880 (1996) recounts the resistance encountered by creative activity in its attempts to enter the critical activity-dominated US higher learning system (Myers 2006: passim). The quote behind Myers' title illustrates:

When Vladimir Nabokov was proposed for a chair in literature at Harvard, the linguist Roman Jakobson objected. "What's next?" he said. "Shall we appoint elephants to teach zoology?" (Myers 2006: v)

The evolution of the exegesis as a research tool in Australian creative arts disciplines begins with the difficulty of acceptance of creative arts practice as research at all in the university context - by administrators especially, and perhaps by academics in science and humanities fields - but it significantly involves the fact that creative artists teaching at tertiary level themselves strongly opposed the notion that what they did was 'research', as the following potted history indicates.

\section{The first creative writing doctorate offered}

In 1985 the University of Wollongong (UOW) was the first Australian university to offer a doctorate which included creative writing. The UOW Doctor of Creative Arts degree (DCA) achieved a high national profile as part of the University's bold curriculum:

The more radical of Wollongong University's offerings were its postgraduate degrees, namely the Master of Creative Arts and the Doctor of Creative Arts ... these were offered in the areas of Musical Composition, Musical Performance, Painting, Drawing/Printmaking, Ceramics, Sculpture, Textiles and 
Creative Writing (including poetry, fiction and drama).

(Dawson 2005: 153)

Creative Writing appeared in the mix due to a happenstance of administrative history. An amalgamation between the University and the local Institute of Education in 1982 brought undergraduate courses in writing side-by-side with visual arts and music courses. When the innovative push for doctoral studies occurred in 1984 under the stewardship of Professor Cowie (himself an Arts polymath, recognised for his music and painting), requirements for creative writing in the new degree went forward alongside those for the visual arts and music.

It is worth pausing to reflect on the contribution Cowie made to the development of the creative doctorate in Australia. In the early 1980s Cowie had pioneered arts practice as research in England at Lancaster University. He was, he says, invited

to form a new research unit that would combine the arts with some science units in a new kind of school. During a year of battle, the scientists were delighted with the idea, but both Theatre and Fine Arts (let alone Music) felt the whole venture to be ridiculous. (Cowie 2010)

In 1983, while touring east coast Australia, he delivered a lecture at UOW based on his ideas about what he called 'Fusion Arts research'. On the basis of that lecture, UOW invited him to found a new school at Wollongong (Cowie 2010).

Cowie's notion of fusion arts research derived from his own multidisciplinary practice: his music was inspired especially by painters, and he "believed that all of the arts languages are derived from central theories of form"' (Cowie quoted in Australian Music Centre 2009). In developing this new concept of research, Cowie had completed a Doctorate in Music and a PhD in Applied Physics (focused on special theories of related forms), and also he had a Slade Diploma in Fine Art (Cowie 2010). His background, spanning various arts and sciences, allowed insight into how research - in the 80 s associated particularly with the humanities and sciences - was also applicable to creative arts. He held no suspicions or scepticism about the 'scholastic rigour' and 'strategic thinking' required by artists in the exegetical situation of writing about their own work. The creative and subjective nature of science research was clear to him: 'My own physics $\mathrm{PhD}$ was practice-based and my writings and mathematics were mine and not someone else's!' (Cowie 2010).

Cowie was an exceptional academic, having insight into a broad disciplinary spectrum of research. His thinking in 1984 prefigures the Strand Report by more than a decade, and ERA by a quarter-century. He wrote in 1984:

"The award of a degree to an Artist who theorises about his or her work, and couples thesis with practical submission, [must be] a viable assessment practice in the tertiary education world. To go beyond that is truly breaking new ground, and yet there is surely a need to recognise that the actual creative work of an Artist constitutes an equivalent to the language of scholarship." (Cowie quoted in Bell 1998: 110)

Cowie also mentions that in the lead-up to his proposal for the UOW doctorate, he contacted 'the then Director of the National Library' in Canberra. The ANL Director, Cowie says: 
supported the idea that any archive that included statements (he readily included thesis AND examples of practice in these archival materials), autographic commentaries, and examples of practices, was something that any curator would be delighted with. (Cowie 2010)

So, in proposing the first doctorate available to creative writers in Australia, Cowie enlisted archivist expertise in recognition of the fact that exegetical commentary on creative process was highly-prized at national cultural levels. Libraries around Australia hold writers' exegetical papers, dating back over decades, which become valuable to researchers in later years. Cowie's idea of a doctorate was that it could at once contain the creative product and also exegetical writing about it.

The first DCA awarded by UOW was in the Visual Arts, conferred on Peter Shepherd. Shepherd states: 'I completed the DCA submission, 'More Than the Portrait', at the end of 1987 and was the first graduate with that degree in May 1988' (Shepherd 2010). By the end of 1989 UOW had graduated 2 DCAs and 3 PhDs in Creative Arts, in the areas of Visual Arts and Music (Shepherd 2010). None of them was in creative writing, the first of which did not appear 'until some time in the 90s' (Pretty 2010).

\section{The first creative writing doctorate conferred}

As Boyd (2009) found, Graeme Harper's DCA in the University of Technology, Sydney (UTS) was the first successful creative writing doctorate in Australia, submitted in 1992 and conferred in 1993. Harper relates that in 1989, when he set out on the project, his supervisor Stephen Muecke

... was open to many possible ways of approaching the doctorate, but also aware of the University's requirements for completion of a doctorate in such areas as the Visual Arts for indications of what he [Harper] should do in order to complete such an award in the creative writing area. (Harper 2010a)

Muecke recalls that Harper 'was very industrious. He wrote a critical journal as well as literary critical essays to supplement his novel' (Muecke 2010). One might surmise that because DCAs were pioneering a way for creative arts postgraduate studies in the late 1980s, and because Creative Writing had limited standing in the Australian academy at this time, the heavy exegetical requirement was imposed by UTS to ensure academic rigour. In fact, Harper himself suggested the parameters for the submission. In a letter he wrote to Muecke on 1 March 1991 (two years after he had started) he said:
"I want to produce for the DCA - (1) the novel (2) a diary much like Steinbeck's East of Eden letters, written on each day of writing (3) a theoretical work related to the text [and] (4) a theoretical work drawing on the text but with more general application." (cited in Harper 2010b)

As is typical of creative writing doctorates now, much preparation, thinking, research, discussion and writing had occurred before the moment when the final shape of the submission was reliably forecast. And in this case there was an earlier recognition of the fact that creative writing doctorate structures didn't come ready-made. Two years prior to his laying down the form in which the submission would occur, Harper had met with his supervisors (in 1989) when 
... Stephen [Muecke] and Gunter Kress in the office at UTS ... kind of float[ed] up in the corner, saying "so this would be a doctorate in Creative Writing we're launching here". (Harper 2010b)

With all its starry-eyed, student-perspective vulnerability acknowledged, I place this moment observed by Harper as the moment in Australian academic history when the first conferred creative writing doctorate was conceived. Candidate Harper watched the supervisors appointed for his undefined doctorate fly angel-like into the corner of the office to pronounce apprehensively the beginning of a genre. Then Harper knuckled down and did it.

\section{International contexts}

Australian creative writing doctorates developed in the context of 1980s and 90s US practice and alongside developments occurring in the UK. While the new Australian doctorate ventured to incorporate the concept of the creative product submission already available in longer-standing US models, there was little in the UK in the late 80s for Australian universities to draw from. Bird (2000), Harper (2003) and Butt (2009) indicate that in the UK at the time, universities were on much the same belated trajectory as Australia. Together the UK and Australia went the route of the 2-part exegesis/critical commentary type of doctorate, not espousing the US model with its 'large taught element, with regular papers to be submitted' (Butt 2009: 53). The UK and Australian degrees focused rather on the student's own work, 'unfurling at its own speed, without term papers' (Butt 2009: 53).

In the US in the 1980s, the 2- or 3-year Master of Fine Arts (MFA) in creative writing involved workshops and academic study which included literature courses, but submission required creative product only, as is still the case. US $\mathrm{PhD}$ programs (with titles such as: ' $\mathrm{PhD}$ in English with a Creative Dissertation') were similar to the MFA, involving literary studies coursework and writing workshops as preparation for the dissertation, and did not involve an exegesis, as is still the case. As Figure 1 indicates, in 1984 there were 20 non-exegetical PhDs in creative writing in the US and 31 MFAs. In subsequent years the MFA took off - now there are six times as many MFA programs, but only a handful more PhDs. Butt (2009) points out that currently around the same small number of creative writing doctorates (approximately 30 each) exist in the US and the UK. To this can be added, there is a similar number in Australia.

Figure 1: Numbers of US Degree-Conferring Programs in Creative Writing 1975-2010

\begin{tabular}{|c|c|c|c|c|c|c|c|}
\hline Year & AA & $\begin{array}{c}\text { BA/BS } \\
\text { minor }\end{array}$ & $\begin{array}{c}\text { BA/BFA } \\
\text { major }\end{array}$ & MA & MFA & PhD & Total \\
\hline 2010 & 12 & 347 & 157 & 116 & $\mathbf{1 8 4}$ & $\mathbf{3 6}$ & 852 \\
\hline 2004 & 10 & 318 & 86 & 154 & 109 & 42 & 719 \\
\hline 1994 & 6 & 287 & 10 & 139 & 64 & 29 & 535 \\
\hline $\mathbf{1 9 8 4}$ & 4 & 155 & 10 & 99 & $\mathbf{3 1}$ & $\mathbf{2 0}$ & 319 \\
\hline 1975 & 0 & 24 & 3 & 32 & 15 & 5 & 79 \\
\hline
\end{tabular}

(AWP 2011: 95) 
The early Wollongong DCA did not follow the US coursework model, nor did any subsequent Australian creative writing doctorate. In order to round out doctoral study that produced a creative product, the Australian model favoured an exegesis above coursework or formal workshops: Australian universities preferred an individual academic research project, based on the concept of an artist's reflective and analytical journal or commentary. I suspect this was done not for pedagogical reasons, but for administrative reasons; with fewer candidates than the American model might call on, it was cheaper to run a doctorate this way.

In Britain in the 1980s, the notion of a doctoral submission incorporating an exegesis was tentatively finding its way. The University of East Anglia (UEA) claims that: 'In the 1980s [it] pioneered a new type of PhD ... UEA was in the forefront of the development of the PhD in Creative Writing' (University of East Anglia 2011a). On another page of their website, UEA claims they accomplished this pioneering 'in the 1970s', not the 1980s (University of East Anglia 2011b). Confusion about their own history may relate to the fact that the UEA creative doctorate, developed initially not just as a creative writing initiative, was multidisciplinary in nature and gave the opportunity to authors, painters and musicians alike to comment critically on the production of their new work. Whatever the case, UEA conferred its first PhD in Creative and Critical Writing in 1990. It was a submission by the Jordanian/British writer Fadia Faqir.

As happened in the UK, in Australia the earliest creative doctorates were undertaken by scholars working in a range of disciplines - music, the visual arts, and writing - which included 'languages' (i.e. expression in painting, ceramics, musical composition, etc) which were not the accepted languages of academia. Universities understood writing or mathematics as the languages of research: they did not understand (though clearly they should have) music or image-making, or other creative languages, by which research could be communicated. Additionally, universities did not see the writing up of a ground-breaking science or math experiment as an exegesis upon a practice.

Also, the exegetical was a strange surprise for painters, musicians and performers in academia in spite of the exemplary practice of their finest mentors (Klee, Kandinsky, Schoenberg, Brecht et al). Creative arts academics did not see the value of writing up a ground-breaking music or painting experiment as an exegesis upon a practice. In line with the university's own confusion about the matter, creative arts academics stuck to understanding best the language of their own artforms (i.e. the language expressed in what came out at the end of their violin-, paintbrush-, or gesture-tickling fingers) rather than that depicted in text on an A4 page. In postgraduate studies, these practitioners were confronted with two essentially different sites of record: that of their practice, and that of their analysis.

Had it remained in the visual artists' or musicians' hands, the form of the exegesis (the 'second' language) would not have changed radically or quickly. In the hands of creative writers, however, the exegesis did change. For creative writers, the site of record of process pursued in the critical product was the same as the site of record of the creative product. The A4 page played the key role here: it was the natural spill-over site for experimentation. While visual arts and music candidates did not presume their experimentation should stray from canvas or musical score, creative writing research scholars felt more confident about playing with the exegesis form. 


\section{The creative writing exegesis sets off on its own trajectory: from reflective text, to parallel text, to plaited text}

The reflective journal exegesis, with its this-is-how-I-wrote-my-creative-piece approach, was soon deemed unexciting by creative writing candidates, supervisors and examiners. In the early 2000s, research scholars who had risen above questions like What is an exegesis? and Why do I have to do one? sought to achieve more with the exegesis form. They and their supervisors discussed the aims and focus of the exegesis and its orientation to the creative product (see dozens of articles in TEXT and, e.g. Fletcher \& Mann 2004). The discussion questioned and attacked the exegesis, and also the gap between it and the artefact. This lent impetus to exploratory experimentation.

Departures from the reflective journal exegesis included the exegesis in the form of an essay providing a conceptual or historical framework - a minidissertation of the style familiar as submission for disciplines such as Literary Studies, Cultural Studies, History, Sociology or Philosophy - i.e. a prose work that swapped the tradition of the Creative Arts journal for traditions of academic writing in other Humanities disciplines. In this parallel text, the candidate might be seen to stop being creative writer, becoming instead the more disengaged and critical humanities academic. However, Butt takes an opposite view on this. She thinks, in examining the impact of outside influences on the writer and the writing, the parallel text 'is a conscious reflection of the largely unconscious act of writing' (Butt 2009: 55).

There's a schizophrenia apparent in this situation. The researching writer, trying to be creative writer, is forced back to the role of critic distanced from the process, as opposed to being critic inside the process. The exegesis here wasn't something home-grown in the Creative Writing discipline - it was an imposition from contextualising, 'more authoritative' disciplines - but was an initial extending of the umbilical cord between artefact and exegesis because it allowed the exegesis to be a parallel commentary with an implied relationship to the artefact, suggesting an added or alternative outcome to the research undertaken in writing the creative product. This raised the status of the exegesis from servant-to-the-master narrative to a sort of equal, to a narrative in its own right. An example of this is Nike Bourke's The Bone Flute - From the cradle to the grave (Bourke 2003), where the novel told a disturbing story about domestic violence and infanticide, and the exegesis was a study of infanticide in contemporary society.

In the early 2000 s there was plenty of room for experimentation. In this context, two of my own candidates tested the idea of parallel texts brought together and plaited in the submission structure. Peter Wise, in The Turns of Engagement: A Thesis / Novel on the Circumstances of Writing (2001), presented exegesis and creative narrative as alternating, mirror-image, theorythen-fiction-then-theory chapters which blended together progressively until creative product chapters became, eventually, indistinguishable from dissertation chapters (Wise 2001). Wise's submission performed the evolution of fictocriticism, the creation of the thesis-slash-novel. It had a hard time passing examination in 2001.

In 2005, another student of mine, Marilynn Loveless, produced $M r s$ Shakespeare: Muse, Mother, Matriarch, Madonna, Whore, Writer, Woman, Wife - Recovering a Lost Life (2005). At Loveless's graduation, the Acting Dean refused to read out the title of her $\mathrm{PhD}$; perhaps he considered it un-academic. The submission involved the chapters of a novel revealing Anne Hathaway as the real writer of Shakespeare's canon being alternated with the chapters of an exegesis about male-dominated discourse in the academy (Loveless 2005). 
Here the plaited texts worked off each other and created their own dialogue; Loveless's discontinuous narrative was about reading the gap between exegesis and artefact, and analysing it.

There's much to learn from the idea of the exegesis and artefact as plaited text. Barthes insisted on the death of the author because the exegetical wasn't present. He asserted that because the writer wasn't present in the work, the reader must alone create the work. But the creative writing doctorate's combination of creative product and exegesis insists on the writer's presence. The plaited text, in showing both the product and aspects of the process or its context, asserts the existence of the author.

\section{The exegesis as runaway text}

After paralleling and plaiting, came a sense of the exegesis as outlaw. I think important room should be made for the outlaw exegesis because new knowledge won't be made by those who obey, or stretch just a little, the laws or status quo. With the understanding that $\mathrm{PhDs}$ are entitled to break new ground in exegetical and artefact areas and must challenge existent forms, I have continued experiments with willing candidates and with the adjudication of mostly-understanding examiners.

My research student, the performance poet Jayne Fenton Keane, was awarded her $\mathrm{PhD}$ in 2008 for a submission titled 3-D Poetic Natures (Fenton Keane 2008). It was a dissertation-length account of the writer's writing and performing processes, but it used radical tactics such as mixing academic prose with poetic musings; incorporating poems and raw notes; citing whale-song; mounting its own green protest campaign; exploring the candidate's own body, its movement and breathing; and generally forcing the blend of the academic with the poetic to the extreme. Wonderfully, the doctorate was awarded the University's Academic Excellence award, which meant the examiners didn't want a single word changed. Fenton Keane's submission can be described as blended: she put the ingredients for artefact and exegesis into a bowl and mixed them. This seeming implosion of the elements of the creative doctorate can be truly termed 'fusion arts research', as Cowie implied.

At another extreme, my student Nicola Boyd, in her Strange Loops and Confessions: In search of a Creative Writing research methodology (Exegesis) and AI PI: A Novel (Creative Component) (Boyd 2010) argued for there being no logic at all to the need for a link between an exegesis and its accompanying creative product. Her exegesis - a massive study of 200 Creative Writing doctorates submitted in Australia from 1993 to 2008, included much statistical work, and many graphs and tables. She claimed it was a valid research contribution to the discipline (which it clearly was). She also claimed that her creative component - a feminist sci-fi private detective novel for young adults - was a valid contribution to the discipline in its own right. The fact that the two parts of the submission had little to do with each other (except that her statistics showed her novel was in the highest category of publishable doctoral products) - she claimed - should not disqualify her submission.

Her submission was successful. With Dr Boyd the umbilical cord between exegesis and artefact snapped ... her exegesis was a complete outlaw. It didn't reflect on, parallel, plait or blend with its creative component. It wasn't practice-led in the conventional sense, where the research is led by the creative work. If anything, it was practice-led by the practice of being a doctoral student! It made sense not in terms of the production of a single work, but in 
terms of far broader research issues related to how the Creative Writing discipline might go forward with a new academic understanding of itself.

In my university we have a flexible notion of the relationship between the exegesis and the creative component. How typical is it? In Australia the tolerance for flexibility is increasing. A brief survey of university websites shows that Flinders University, in South Australia, still has a rather traditional concept of the exegesis:

The critical research relates specifically to the student's individual creative product, providing a conceptual framework and usually setting it in a contemporary artistic, cultural and/or historical context by examining exemplary texts. (Department of English, Creative Writing \& Australian Studies 2010)

Curtin University, in Western Australia, seems constrained by the traditional approach and is attempting to work its way out:

... the exegesis does not provide a direct commentary on the production, nor does the production simply illustrate the exegesis - rather both elements maintain the integrity of the specific discourse (or language) in which they are created, and "speak to" each other through their common purpose of elucidating a response to the research question. (Curtin University of Technology 2008)

On the other hand, the University of New South Wales is entirely committed to flexibility. Its web page titled 'The structure of our research degrees' states:

Unlike many other writing programmes, we do not encourage an exegetical relationship between the two components, where the critical work makes manifest the aesthetic and theoretical rationale for producing the creative work, or provides an interpretative template for assessing it. Instead, we encourage a far more flexible connection between the creative and the critical: a complementary and dialogic relationship, rather than a supplementary and explanatory one. (School of English, Media and Performing Arts 2010)

The creative writing exegesis has picked up momentum on its liberating trajectory. A similar trajectory is now predicted for the creative component.

\section{Conclusion: the further radicalisation of the Creative Writing doctorate}

In Australia in 2010 creative academic work was first recognised as research under ERA (Excellence in Research for Australia) and consequently now attracts government funding like other disciplines' research publishing (Australian Research Council 2009). Under these policy arrangements, a creative work is proven to be research on basis of having a 2000-character Research Statement attached, with the creative piece and the statement peer reviewed by national panels. The Research Statement is clearly a descendent of the exegesis with its form prescribed; it must comprise information about the creative work in 3 areas:

\section{Research Background}

- Field 
- Context

- Research Question

2. Research Contribution

- Innovation

- New Knowledge

\section{Research Significance}

- Evidence of Excellence (Australian Research Council 2009)

At two levels - in creative research publications by staff and research students, and in the creative doctorate - Creative Writing departments are now encouraged (perhaps, required) to produce creative pieces which make innovative contributions to new knowledge. Inevitably this new knowledge expresses itself in creative works which question and extend language, forms and genres. While publishers have typically retracted support from the avantgarde in writing, and stick to notoriously non-experimental, money-making ventures, universities have a new role to play. We need to become more vitally concerned that the creative writing $\mathrm{PhD}$ is a site where radical experimentation, for the sake of progressing the literature and knowledge, must take place.

Our recognising this involves a re-think of the 'publishability' criteria applied to our doctoral products. The academic novel, story or poem collection, etc may not necessarily be subject to requirements for ordinary public consumption: they may be 'publishable' only if an imagined publisher existed gutsy enough to publish them. As the site for groundbreaking creative work not just competent, or even excellent work - the doctoral artefact has many more pressures attached to it. Alongside those pressures, the candidate must be able to explain why the work is groundbreaking, and is therefore research which adds pressure to the exegesis too. The exegesis (whether reflective, parallel, plaited or outlaw) must continue as a site for radical experimentation.

In light of all this, I'm heartened by a PhD from Murdoch University, Western Australia, which I examined recently: Michelle Crawford's Fingerprints:

Exploration of Identity, Community and Place (Crawford 2010). It includes an exegesis which is something home-grown in the Creative Writing discipline. This exegesis doesn't just operate as a parallel text to the accompanying novel, it is itself an artefact, a system of parallel texts. It's an exegesis not just concerned with its novel, it's self-consciously about writing itself. Its pages are set out in two columns: the exegesis narrative takes up two-thirds of the page in the right-hand column. The left-hand third of the page is a column devoted to a number of font-coded insertions: direct quotes from primary and secondary sources; samples from the candidate's writing journals; excerpts from manuscript drafts along the way; formal material which might be called footnotes; and informal material such as snippets from remembered conversations or notes scribbled on scraps of paper discovered under the floor mat in the car. It's a marvellous investigation and record of the process of writing an exegesis.

\section{Figure 2: Two pages from Michelle Crawford's exegesis}




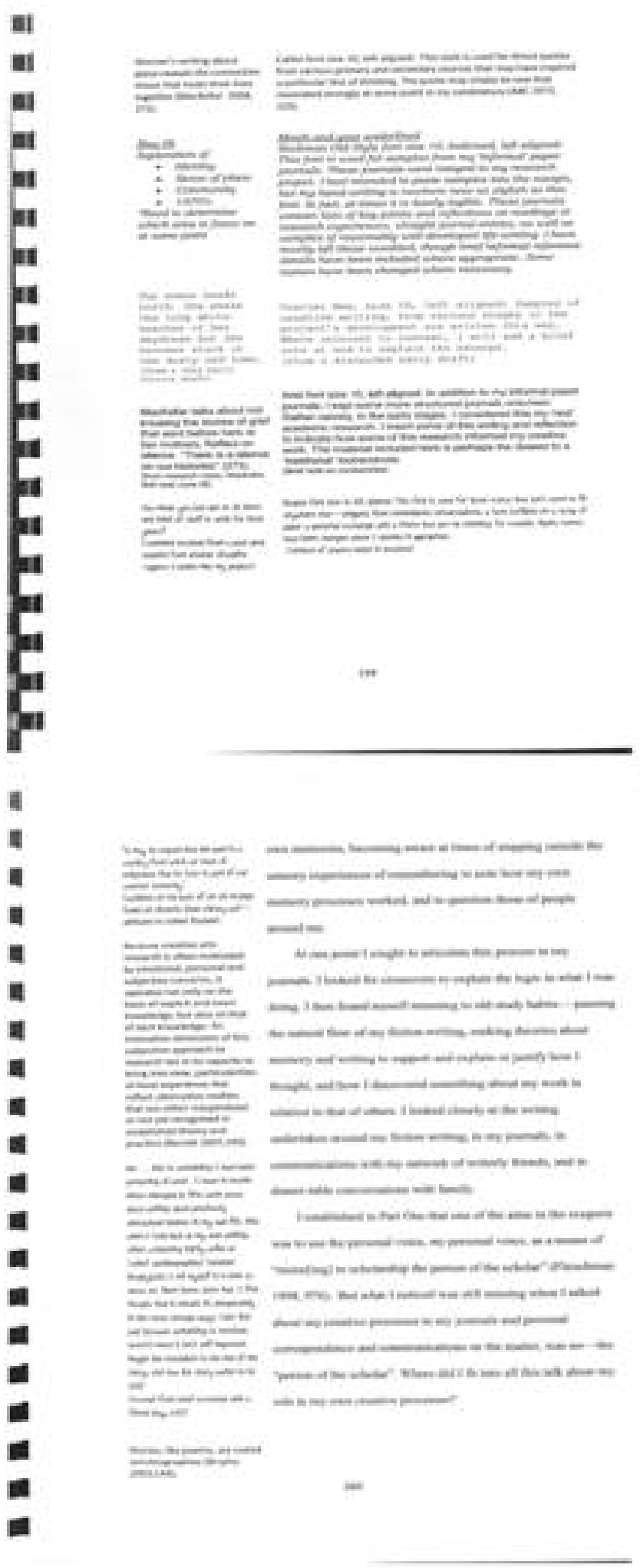

(Crawford 2010) See also in pdf form: click here

This sort of radical writing and thinking, this breaking out beyond formal structures, will keep creative writing research vibrant and valid. There are many sites in the creative writing doctorate where experimentation can occur. While artefacts and exegeses need to establish their new contributions to knowledge, there's also a moment of radical tension between them - before the umbilical cord snaps, before the blending implodes - where experimentation can occur. 


\section{Acknowledgments}

Particularly I acknowledge the generous assistance of Edward Cowie, Graeme Harper, Stephen Muecke, Ron Pretty and Peter Shepherd in providing information for the development of this paper. The two pages of Michelle Crawford's PhD submission are reproduced with kind permission of the author.

\section{Works cited}

AWP 2011 AWP Director's Handbook: Guidelines, Policies, and Information for Creative Writing Programs, The Association of Writers \& Writing Programs, George Mason University, Fairfax, VA http://www.awpwriter.org/pdf/DirectorsHandbook2011.pdf (accessed 13 March 2011) return to text

Australian Music Centre 2009 'Edward Cowie', Represented artists http://www.australianmusiccentre.com.au/artist/cowie-edward (accessed 10 March 2011) return to text

Australian Research Council 2009 'Appendix D: Contents of Research Statement for ERA Peer Review of Non-Traditional Research Outputs’ ERA 2010 Submission Guidelines, Commonwealth of Australia, Canberra, p.77

http://www.arc.gov.au/pdf/ERA2010_sub_guide.pdf (accessed 11 June 2010) return to text

Bell, S 1998 'The Doctor of Creative Arts: Mature Cheese or Bad Wine?' in TW Maxwell and PJ Shanahan (eds) Professional Doctorates: Innovations in Teaching and Research, Armidale, NSW: University of New England, pp. 109-13 return to text

Bird, E 2000 'Research in Art and Design: the first decade', Working Papers in Art and Design 1 (November) http://sitem.herts.ac.uk/artdes_research/papers/wpades/vol1/bird2full.html (accessed 19 February 2011) return to text

Bourke, N 2003 The Bone Flute - From the cradle to the grave PhD submission, Griffith University, Gold Coast, Queensland return to text return to text

Boyd, N 2009 'Describing the creative writing thesis: a census of creative writing doctorates, 1993-2008' TEXT: Journal of writing and writing courses 13, 1 (April) http://www.textjournal.com.au/april09/boyd.htm (accessed 10 June 2010) return to text

Boyd, N 2010 Strange Loops and Confessions: In search of a Creative Writing research methodology (Exegesis) and AI PI: A Novel (Creative Component) $\mathrm{PhD}$ submission, Griffith University, Gold Coast, Queensland return to text

Butt, M (2009) 'Creative writing research degrees: range and rigour', New Writing 6, 1: 5356. http://eprints.mdx.ac.uk/4098/1/Butt-Range_and_rigour.pdf (accessed 19 February 2011) return to text

Cowie, E 2010 Email correspondence, 9 October 2010 return to text

Crawford, M 2010 Fingerprints: Exploration of Identity, Community and Place PhD submission, Murdoch University, Murdoch, Western Australia return to text

Curtin University of Technology 2008 Guidelines for Creative Production Theses http://research.curtin.edu.au/local/docs/graduate/GS-CreativeProdThesesGuidelines.pdf (accessed 7 June 2010) return to text

Dawson, P 2005 Creative Writing and the New Humanities Routledge, London return to text

Department of English, Creative Writing \& Australian Studies 2010 Creative Writing Handbook School of Humanities, Flinders University http://www.flinders.edu.au/shadomx/apps/fms/fmsdownload.cfm?file_uuid=9F34C0F1-BFEAF341-64B0-757C17DE250B\&siteName=ehlt (accessed 7 June 2010) return to text

Fenton Keane, J 2008 3-D Poetic Natures. PhD submission, Griffith University, Gold Coast, Queensland return to text 
Fletcher, J \& A Mann (eds) 2004 Illuminating the Exegesis TEXT Special Issue No 3 (April) http://www.textjournal.com.au/speciss/issue3/content.htm (accessed 10 June 2010) return to text

Harper, G 2010a Email correspondence, 30 July 2010 return to text

Harper, G 2010b Email correspondence, 12 August 2010 return to text

Harper, G 2003 'A State of Grace?: Creative Writing in UK Higher Education, 1993-2003' TEXT: Journal of writing and writing courses 7, 2 (October)

http://www.textjournal.com.au/oct03/harper.htm (accessed 19 February 2011) return to text

Kahlo, F 1995 The Diary of Frida Kahlo: An intimate self-portrait (Intro. Carlos Fuentes; Essay and Commentaries Sarah M. Lowe) New York, Abrams return to text

Loveless, M 2005 Mrs Shakespeare: Muse, Mother, Matriarch, Madonna, Whore, Writer, Woman, Wife - Recovering a Lost Life. PhD submission, Griffith University, Gold Coast, Queensland return to text

Muecke, S 2010 Email correspondence, 31 July 2010 return to text

Myers DG 2006 The Elephants Teach: Creative Writing Since 1880. University of Chicago Press, Chicago return to text

New, J 2005 Drawing from life: The journal as art. New York: Princeton Architectural Press return to text

Pretty, R 2010 Email correspondence, 23 July 2010 return to text

School of English, Media and Performing Arts 2010 'The Structure of our Research Degrees', Creative Writing at UNSW University of New South Wales, Arts and social Sciences http://empa.arts.unsw.edu.au/creative-writing-resources/creative-writing-at-unsw/ (accessed 7 June 2010) return to text

Shepherd, P 2010 Email correspondence, 29 August 2010 return to text

University of East Anglia 2010 'History of Creative Writing at UEA', http://www.uea.ac.uk/creativewriting (accessed 8 September 2010)

University of East Anglia 2011a 'Creativity Postgraduate and PhD Research' http://www.uea.ac.uk/hum/creativity/PhD-by-practice-creativity-research (accessed 13 March 2011) return to text

University of East Anglia 2011b 'The Creative-Critical PhD by Practice' http://www.uea.ac.uk/hum/creativity/PhD-by-Practice-Creative-Critical-Writing-Art (accessed 13 March 2011) return to text

Wise, P 2001 The Turns of Engagement: A Thesis / Novel on the Circumstances of Writing. $\mathrm{PhD}$ submission, Griffith University, Gold Coast, Queensland return to text

Nigel Krauth teaches writing at Griffith University, Gold Coast. With Kevin Brophy he is co-editor of TEXT: Journal of Writing and Writing Programs www.textjournal.com.au.

\section{TEXT}


http://www.textjournal.com.au

Editors: Nigel Krauth \& Kevin Brophy

Text@griffith.edu.au 